\title{
GRECKI PRZEKŁAD KSIĘGI DANIELA W ŚWIADECTWACH PATRYSTYCZNYCH
}

Język Księgi Daniela stanowi jedno z trudniejszych zagadnień, jakie stają przed egzegetą przy studium tej księgi. Sam jej tekst masorecki jest dwujęzyczny: hebrajski /1, 1-2, 4a 1 8, 1-12, 13/ oraz aramejski $/ 2,4 b-7,28 / 1$ i fodatku krótszy. Nie posiada bowiem tzw. części deuterokanonicznych tj. pieśni Azariasza i trzech młodzieńców /Dn 3, 24-90 według łacińskiej Wulgaty /Vg/ oraz opowiadań o Zuzannie /Dn $13 \mathrm{Vg} /$, o Belu i smoku /Dn $14 \mathrm{Vg} /$. Pełny tekst Księgi Daniela obejmujący zarówno partie proto-, jak też 1-deutero-kanoniczne, ma przekład grecki. Ale ten właśnie grecki przekład tradycja przekazała w dwóch wersjach: Siedemdziesięciu /LXX $/^{2} 1$ w tzw. przekładzie Teodocjona/T/. I tu zaczyna się nowy problem. Grecki przekład całego Starego Testamentu reprezentuje LXX. Tymczasem w odniesieniu do Ksiegi Daniela powszechnie przyją się przekład T.

1 Komentatorzy nie sa jednomyślni w wyjaśnianiu tej kwestii. Jedni uważają, że Księga Daniela pochodzi od autora z kręgu chasydów i była redagowana w języku hebrajskim, materiał zaś źródłowy, z którego korzystał autor-redaktor, pisany w języku aramejskim, został przez niego włączony w tekst dzieła w jęyku oryginalnym /tak sądzi np. M. Delcor, Le livre de Daniel, Paris 1971, 10-20, 36/. Inni natomiast są przekonani, że Księga' Daniela była redagowana w języku aramejskim, a partie języku hebrajskim sa tłumaczeniem z jezyka aramejskiego/tak np. A. Di Lella, The Book of Daniel. A New Translation with Introduction and Commentary by L. F. Hartman and A. Di Lella. The Anchor Bible 23, Garden City, N. Y. 1980, 14-18, 73/. W moim przek onaniu hipoteza pierwsza jest bardziej przekonywająca, zwłaszcza gdy się weźmie pod uwage racje przemawiające za jednością Księgi, tak zróżnicowanej pod względem forny literackiej.

2 Sw. Hieronim nazywa go: "vulgata editio". Por. PL 25, 498 A, 576 C. J. Ziegler we Wstępie do swego krytycznego wydania greckiego przekładu Księgi Daniela/Septuaginta. Vetus Testamentum Graecum auctoritate Societatis Litterarum Gottingensis editum XVI, 2, Gottingen 1954, 7/przeñład ten określa znaikiem "o" "i uważa go za tekst piątej kolumny Heksupli Orygenesa $/=$ trzecia jego Tetrapli/. 
Co o tej zmianse zadecydowało? Co na teu tecat mocina powiedzieć w oparciu o mypowiedzi 1 świadectwa Ojców 1 Pisarzy Kościoła? oto pytania, które przy studium Księgi Daniela niemalze spontanicznie się narzucają i na które spróbujemy dać odpowiedź.

\section{PRZEKLAD LXX}

Tekst grecki Księgi Daniela w wersji LXX dotarł do naszych czasów tylko w dwóch rękopisach, a mianowicie w kodeksie minuskuło. wym 88, zwanym kodehsem Chigi /Codex Chisianus/ z IX w. po Chr., znajdującym się obecnie w Bibliotece Tatykańskioj ${ }^{3}$ i w kodeksie syroheksaplarnym, przechowywanym w Bibliotece Ambrozjariskiej w Mediolanie $e^{4}$. Tekst Księgi Daniela w tych rękopisach mimo różnicy językowej jest prawie jednobrzmiący ${ }^{5}$. Brzmienie tekstu tej właśnie wersji /LXX/Księgi Daniela potwierdzają 1 od strony krytycznej w pewnym stopniu uzupełniaja fragmenty greckiego jej przekładu przedheksaplarnego, zachowane na papirusie nr 967, zwanym papirusem Chester Beatty z pierwszej połowy III w. po Chr., którego częś

3 Kodeks ten po raz pierwszy wydał Simon de Magistris: "Daniel secundum Septuaginta ex Tetraplis origenis nunc primum editus e sj gulari Chisiano codice annorum supra DCCC", Romae 1772. To wydanie było podstawą dalszych wydań przekładu LXX-Daniela; por. J. Ziegler, dz.cyt., 27-28.

4 Ten rękopis, gdy chodzi o Księge Daniela, jest bardzo wiernym przekładem syryjskim, pisanym najstarszym alfabetem syryjskim zwanym estrangelo, dokonanym w latach 615-617 z greckiej Tetrap] Orygenesa przez bp Pawła z Tel11. Po raz pierwszy wydał go C. Bl gati/Mediolan $1788 \mathrm{r} . /$, a później A. M. Ceriani/Codex syro-hexaplaris ambrosianus photolithographice editus. Monumenta sacra et profana, vol. VII, Mediolani 1874, 143r-151v/. Grecki kolofor tego kodeksu podobnie jak kolofon kodeksu minuskułowego 88 w tłi maczeniu brzmi: "Daniel według Siedemdziesieciu; został przepis ny z egzemplarza majçcego następującą adnotację: "Przepisany z Tetrapli 1 według niej uzupełniony" /oczywiście notami krytycz nymi Orygenesa. Koniec kolofonu Syh brzmi: "z którą był porównywany"/. Por. Septuaginta id est Vetus Testamentum graece Iuxta $L$ interpretes, Edidit A. Rahlfs, vol. II: Libri poetici et prophetici, Stuttgart 1935, 864.

5 "mire concordantes" stipierdza A. Rahlfs/dz.cyt.,864/. Obydwa te kodeksy oraz ich wzajemny stosunek do siebie omónił M. Lohr, Textkritische Vorarbeiten zu einer Erklarung des Buches Daniel, $\mathrm{ZAW} 15 / 1895 / 75-103,193-225 ; 16 / 1896 / 17-39$. 
znajduje się w Londynie ${ }^{6}$, a część w Kolonii ${ }^{7}$.

Dzieje tekstu wyżej wymienionych rękopisów, zdaniem niektórych Krytyków, mskazują, ze przekazany przez nie przekład LXX-Daniela jest raczej recenzją, anizeli pierwszym przekładem, którego dokonano z tekstu hebrajskiego, najprawdopodobniej w Aleksandri1 ${ }^{8}$. Spróbujmy zatem zapoznać sie ze świadectwami ojców 1 Pisarzy Kościoła, którzy posługiwali sie tym przekładem, lub na niego się powoływali; ich bowiem świadectwa rzucają pewne światło, tak na wartość tego przekładu, jak też na czas 1 zasięg posługiwania się nim wościele.

Warto jednak na wstępie zauwaźyć, że grecki przekład I Księgi Machabejskiej posiada kilka wyrażeń zaczerpniętych z przekładu LXX-Daniela9. Jeżeli się przyjmie, że I Księga Machabejska została przełożona z języka hebrajskiego na język grecki ok. 100 r. przed Chrystusem, a takie jest przekonanie prawie wszystkich komentatorów tej Księgi, to mozna stąd wnosić, iz przekład LXX-Daniela juz w tym czasie istniał. To z kolei wskazywałoby, ze przekładu Księgi Daniela na język grecki dokonano wnet po jej powstaniu, a więc mniej więcej 50 lat po jej ukazaniu się, skoro ogólnie przyjmuje się, iż jej redakcja nastąpiła w czasach machabejskich /167-164 r.prz. Chr./. Również pewne słowa

6 Tę część wydał F. G. Kenyon, The Chester Beatty Biblical Papyri. Descriptions and Texts of Twelve Manuscripts on Papyrus of the Greek Bible, rasc. VII: Ezek1el, Daniel, Esther, Lond on 1937, 17-38.

7 Opublikowali ją: A. Geissen, Der Septuaginta-Text des Buches Daniel. Kap. 5-12 zusammen mit Susanna, Bel et Draco nach dem Kolner Teil des Papyrus 967, Papyrologische Texte und Abhandlungen 5, Bonn 1968; W. I Iam, Der Septuaginta-Text des Buches Daniel. Kap. 1-2 nach dem Kolner 'Teil des Papyrus 967, Papyrologische Texte und Abhandlungen 10, Bonn 1969; tenże, Der Septuaginta-Text des Buches Daniel. Kap. 3-4 nach dem Kolner Teil des Papyrus 957, Papyrologische Texte und Abhandlungen 21, Bonn 1977.

8 Zagadnienie stosunku tego przekładu do tekstu oryginalnego, tj. hebrajskiego - aramejskiego, stanowi osobny prablem. Omawiają go szczegółowo: A. Bludau, Die alexandrinische Ubersetzung des Buches Daniel und ihr Verhaltnis zum massoretischen Text, Biblische Studien II, 2-3, Freiburg 1. Br. 1897 oraz we IVstępach do swych komentarzy: J. A. Montgomery, A Critical and Exegetical Comentary on the Book of Daniel/ICC/, Edinburgh 1927, 35-37 1 R. H. Charles, A Critical and Exegetical Commentary on the Book of Daniel, oxford 1929, LIX-LXX. Podczed gdy ich ocena przekładu LXX-Daniela jest umiarkowana, a nawet pozytywna, to opinia F. Fielda/Origenis Hexaplorum quae supersunt, vol. I, Oxonii 1875, XXXIX/ jest zdecydowanie negatywna: "/.../ tam putide et praepostere iacet, ut nulla manu medica ad Ecclesiae usum accommodari posset".

9 Krytycy wynieniają następujące wiersze: I Mch 1, 9 - Dn 12, 4; 
zaczerpnięte z Ksişgi Daniela w "Antiquitates Judaicae" Józefa Flawiusza ${ }^{10}$, a przede wszystkim cytaty i aluzje w Ksiegach Nowego Testamentu ${ }^{11}$, potwierazają nie tylko istnienie, ale takze szeroko rozpowszechnioną znajomość przekładu LXX-Daniela w I w. po Chrystusie. Zdaniem J. Zieglera ${ }^{12}$ również najstarsze pisma chrześcijańskie posługiwały się przekładem LXX-Daniela, jak autor "Listu Barnaby"13, św. Klemens Rzymski 14 Hermas w "Pasterzu". Nie są to wprawdzie cytaty dosłowne, tym nieıniej wyraźnie wskazują na znajomość przekładu LXX-Daniela.

$\$$ w. J u s t y n męczennik/+165/, słynny apologeta II w., przytacza w swoim "Dialogu z Lydem Tryfonem" dฉ̌uższy cytat z Księgi Daniela $/ 7,9-28 /$ według przekładu LXX ${ }^{15}$.

T e r t u 1 i a n / 220/, którego świadectwo w odniesieniu do Księgi Daniela jest również ważne, posługuje się w zasadzie tekstem suponującym przekład Lxx, chó́ nie jest mu obcy przekład T-Daniela. Cytaty oparte o przekład LXX są rozsiane w różnych jego pismach, jak w "Adversus Marcionem", w "De carne Christi", w "Adversus Praxeam", w "De ieiunio", w "Scorpiace"16.

1 Mich 1, 18 - Dn 11, 26; I Mch 1, 54 - Dn 11, 31 /zob. także 9, $27112,11 / ; 1 \mathrm{Mch} 4,41,43-\mathrm{Dn} 8,14 . \mathrm{Zob}$. A. Di Lella, $\mathrm{dz}, \mathrm{cyt}, 78$.

10 Antiquitates Judaicae X 190 - Dn 1, 12, 16 .

11 Wymienia się następujące: Mt 24, $30126,64-$ Dn 7,$13 ;$ obj 1 , $14 \mathrm{a}-\mathrm{Dn} 7,9 ; \operatorname{obj} 1,14 \mathrm{c}-\operatorname{Dn} 10,6 ;$ obj 4, 1 - Dn 7, 6; Obj 10, 1 - Dn 10, 6; Obj, 10, 5-6 - Dn 12, 7; obj 20, 12 - un 7, 1; obj 14, 14-16 - Dn 7, 13; obj 20, 15 - Dn 12, 1. Por. P. Grelot, Les versions grecques de Daniel, "Biblica" 47/1966/381-402, zwłaszcza 390.

12 Przykłudy ojców zamieszczone niżej są zaczerpnięte z jego pstępu do krytycznego wydania greckiego tekstu Księgi Daniela/zob.pri 2, s.22-27\% Przytoczone tan świadectwa są nie tylko wyczerpujące, ale najbardziej autorytatywne. Totez na ich podstawie będziemy opierać wnioski właściwe dla omawianeyo przez nas tematu, choć u J. Zieglera świadectwa te służą innemu celowi.

13 Epistola Barnabae 4, SCh 172, 92-96 - Dn 7, 24 i 9, 24-27; 16, SCh 172, 188-194-Dn 3,24, 25, 27. Inne miejsca por. Index scripturaire, SCh $172,224$.

14 Epistola ad Corinthios 34, $\mathrm{SCh} 167,156$ - Dn 7, 10. Inne miejsca por. Index Scripturaire, $\mathrm{SCh} 167,216$.

15 Dialogus cum Tryphone Judaeo 31, PG 6, 540C - 541D.

16 Adversus Marcionem III 7,4 i IV 39, 11, CCL 1, 516-517 $1653=$ Dn 7, 13-14; De carne Christi 15, 1, CCL 2, $901=$ Dn 7, 13a; 
or y g e n e s / + 254/w zasadzie posługiwał się przekładen T-Daniela. Jednakowoż w czterech przypadkach sięgnął do przekładu LXX, a mianowicie w apologii "Contra Celsum"17, gdzie pojawia się dwukrotnie tekst Dn 2, 21, oraz w liście "Ad Africanum"18, gdzie są również dwa cytaty: Dn 3, 24 i 3, 90-91 a. W' dwóch przypadkach oryfrenes wyraźnie zaznacza, ze cytowany przez niego tekst Daniela jest wzięty z przekładu Lxx. Ma to miejsce w komentarzu do Mateusza ${ }^{19}$, gdzie cytuje Dn $3,86 a$ i w homilii do Księgi Liczb ${ }^{20}$, gdzie powołuje się na Dn 1, 17, 19b-20.

S . C y p r 1 a n / $258 /$ zdaniem krytyków korzystał ze starołacińskiego przekładu Księgi Daniela, dokonanego z LXX, poprawionego łacińskim przekładem $\mathrm{T}^{21}$. Cytaty zaś z LXX-Daniela znajdują się w jego "Ad Quirinum testimoniorum libri III", w "De lapsis" oraz w "Ad Fortunatum de exhortatione martyrii"22.

W $\mathrm{i}$ k t o r y n z P e t $\mathrm{t}$ a $\mathrm{u} /+304 /$ korzystał z przekładu łacińskiego, dokonanego z LXX-Daniela. Przekład ten jest dlatego cenny, że nie pochodzi z rejonu łacińskiej Afryki. Cytaty z Księgi Daniela znajdują się w jego "Scholionach do Księgi objawienia św. Jana" 23 .

E u z e b 1 u s z z C e z a r e 1 / $/+333 /$ cytuje w swoich pismach teksty z Księgi Daniela zarówno z przekładu LXX, jak tez

Adversus Praxeam 3, $4116,6, \mathrm{CCL} 2,116211182=\mathrm{Dn} 7,10$ i Dn 3, 92; De iejunio $7,819,3$ i 10, 13, CCL 2, 1264, 1265 $11269=$ Dn $9,1 a, 3 c, 23 b$ i Dn 10, 1a, 2-3 i Dn 9, 21; Scorpiace $8,6=$ Dn $3,16 \mathbf{b}-18$.

17 Contra Celsum VIII 68, PG 11, 1620.

18 Epistola ad Africanum 2, PG 11, 49 i 52 .

19 Commentaria in Matthaeum XIII 2, PG 13, 1093 C.

20 In Numeros hom. 18, 3, PG 12, $715 \mathrm{D}$.

21 Por. A. Bludau, dz.cyt., 19.

22 Ad Quirinum II 17 i $26, \mathrm{CCL} 3,53 \mathrm{i} 63=\mathrm{Dn} 2,31 \mathrm{~b}-35 \mathrm{i}$ Dn 7 , 13-14; De lapsis $31, \operatorname{CCL} 3,238-239=\operatorname{Dn} 3,2519,4 \mathbf{b}-7 \mathbf{a}$;

Ad Fortunatum 11, CCL $3,204=\mathrm{Dn} 14,5 \mathrm{~b}$. Inne miejsca $\mathrm{z}$ Daniela por. Index locorum S. Scripturae, CCL 3, 280 .

23 Scholia in Apocalypsin beati Joannis 13 , PL $5,338-340=$ Dn 2 , $34-35,38-40,43 a-44 a ; 7,8 a, 18 a ; 11,37,38,45 a$. 
z T. Z wersji LXX pochodzą cytaty zawarte przede wszystk1m w "Eclogae propheticae" 24 .

Poza cytatami wymienionych wyzej 0jców 1 Pisarzy Kościoła, pochodzącymi bezpośrednio lub pośrednio ${ }^{25}$ z wersji LXX-Daniela, odniesienia do tegoż przekładu znajdujemy jeszcze m.in. u św. Epifanłusza z Salaminy / + 403/ w jego "Adversus haereses"26, u św. Hieronima $/+420 / w$ "Komentarzu do Ksiegi Daniela"27, ktory oparty jest wprawdzie na przekładzie T., ale często odnosi się takze do wersji LXX oraz w pochodzących z 411 r. "Consultationes Zacchaei et Apollonii" 28 Co nam te świadectwa mówia? Najpierw wskazuja, że przekład LXX-Daniela pojawił się bardzo wcześnie, bo już ok. 50 lat po ukazaniu się tej Księgi. Dalej, na podstaw1e powyższych świadectw możemy stwierdzić, że tekst LXX-Daniela zawierał części deuterokanoniczne ${ }^{29}$. Księge Daniela uważano za księgę prorocką i jak świadcza owe dwa kodeksy /88 1 Syh/ umieszczano ją wśród zbioru proroków/przed Ks1ęgą Ezechiela/. Nie ulega wątpliwośc1, że wersja LXX-Daniela cieszyła się

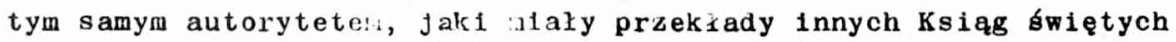
tej samej wersji. Nie trudno jednak zauważyć, iz obok niej istniała równiez bardzo wcześnie powstała wersja T-Daniela, którą zaczęto się coraz częściej posługiwać. W oparciu o świadectwa św. Justyna, Tertuliana, św. Cypriana 1 Wiktoryna z Pettau można przypuszczać, że

24 Eclogae propheticae III 42 i 43 oraz IV 13, PG 22, 1172-1173 11174 oraz $1220=$ Dn 2, 44-45a i 3, 91, 92 oraz 2, 36b.

25 Bliższe szczegóły dotyczące starołacińskich cytatów z Ksiegi Daniela podaje F. C. Burkitt, The old Latin and Itala. Texts and Studies IV, 3, Cambridge 1896, 6-8. 18-31. Note 1. The Use of the LXX Text of Daniel in Latin Writers.

26 Adversus haereses XXXIV $181 \mathrm{LXX} 6, \mathrm{PG} 41,617$ i PG 42, $348=$ Dn 12, 9-10 17 , 9.

27 Commentaria in Danielem prophetam, CCL 75A, 771-913. Por. wykaz komentowanych wierszy z Ksiegi Daniela w Index locorum S. Scriptu rae, CCL 75A, 994-999.

28 Consultationes Zacchaei christiani et Apollonil philosophi II 6, PL 20, $1118=$ Dn $7,13-14$.

29 Por. H. H. Pfeiffer, History of New Testament Times with an Introduction to the Apocrypha, New York 1949, 441-442. Warto w tym miejscu zwrócić uwage na artykuł J. Schtlpphausa, Das Verhaltnis von LXX- und Theodotion-Text in den apokryphischen Zusatzen zum Daniel Buch/ZAW 83/1971/49-72/, w którym omawia charakterystyczne cechy obydwóch wersji/LXX $i \mathrm{~T} / \mathrm{greck}$ iego tekstu deuterokanonicznych części Księgi Daniela. W Jego przekonantu wersja LXX-Dantela cheiała dodać odwagi i skłonié do 
w Kościele Zachodnim czas posługiwania się wersją LXX-Daniela przedłużył sie do III wieku ${ }^{30}$. Świadectwa natomiast orygenesa 1 Euzebiusza z Cezarei dowodzą, ze wościele Wschodnim przestano się tym przekładem posługiwać w 2. poł. II w. po Chrystusie. S. Jellicoe 31 jest zdania, ze stało się to dzięki Orygenesowi. W każdym razie pod konłec IV w. św. Hieronim mógł stwierdzić, że w Kościele nie czyta się juz Księgi Daniela według przekładu LXX, lecz używa się przekładu $\mathrm{T}^{32}$.

\section{PRZEKLAD T.}

Na samym wstępie należy zwrócić uwage, ze w odniesieniu do Księgi Daniela wyrażenie: "przekład Teodocjona" /T/ nie oznacza w ścisłym znaczeniu tego przekładu, który w stosunku do innych Ksiag świętych przyoisuje się Teodocjonowi, osobie zyjącej w czasach cesarza Kommodusa/180-192/33. W rzeczywistości bowiem chodzi

większego wewnętrznego 1 zewnętrznego zaangażowania separującej się od świata pogańskiego wspólnoty wiernych. Wersja zaś T-Daniela usiłowała pocieszyć $i$ dac pełne nadzlei obietnice wspólnocie wierzących, prześladowanych w różny sposób/duchowo 1 fizycznie/ przez agresywnych pogan.

30 R. H. Pfeiffer /dz.cyt. 440, 443-444/ jest przekonany, że w Kościele Wschodnim przestano sie posługiwać przekładem LXX-Daniela juź w latach 150-200, w Kościele Zachodnim zaś w latach 230-250. Natomiast S. Jellicoe/The Septuaginta and Modern Study, Oxford 1968, 86-87/ uważa, iź wościele Zachodnim nastąpiło to dopiero w 2. poł. III wieku.

31 Dz.cyt., 87 .

32 W Przedmowie do swego komentarza do Księgi Daniela pisze: "Illud quoque lectorem admoneo, Danieler non luxta LXX interpretes, sed iuxta Theodotionem Ecclesias legere". /PL 25, 493A/; "et hoc cur acciderit, nescio /... Iloc unum affirmare possum, quod multum a veritate/domyślne: hebraica - tak św. Hieronim nazywal tekst oryginalny/discordet et recto iudicio repudiatus sit"/PL 28 , 1291/. Komentując zaś wiersz Dn 4, 6 ubolewa, że LXX nie ma tégo tekstu 1 mówi: "Unde iudicio magistrorum Ecclesiae editio eorum/LXX/ in hoc volumine repudiata est; et Theodotionis vulgo legitur, quae et hebrae et ceteris translatoribus congruit" $/ \mathrm{PL} 25,514 \mathrm{~A} /$.

33 Wiadomość o Teodocjonie tłumaczu Ksiag św. Starego Testamentu pochodzi od Epifantusza z Salaniny, który zatileścił jaz w dziele "De mensuris et ponderibus" /17, PG 43, 263/, pociodzacym z 392 r. w siowach: "/.../ hoc est Commodo ailero imperante, /.../ 
tu o przekład nieznanego tłumacza/-y?/, który istniał juz w I w. po Chr. obok LXX, a więc przed Teodocjonem ${ }^{34}$.

Przekład T ma bogatą dokumentację $e^{35}$. Poza kodeksami uncjalnymi: A /aleksandryjski z IV w./, B /watykański z IV w./, Q/marchaliański z VI w./ 1 V /wenecki z VIII w./ wersję T-Daniela posiada Jeszcze 40 kodeksów minuskułowych, pochodzących z X-XVI w. z tym, że te ostatnie zawieraja tekst bardzo niekompletny, lub wręcz fragmentaryczny. Bardzo ważny jest jednak fakt, że ten przekład był znany ojcom i Pisarzom Kościoła oraz, że zaczęto się nim posługiwać bardzo wcześnie.

Znał przekład T-Daniela 1 korzystał z niego Józef Flawiusz ${ }^{36}$. Posługiwali się nim hagiografowie Nowego Testamentu / Mk 14, 62 - Dn 7, 13; $\operatorname{Hbr} 11,33$ - Dn 6, 22/, zwłaszcza autor Księgi Objawienia:

Theodotio quidam genere Ponticus ex Marcionis Sinopensis haeresiarchae factione suis partibus offensus ad Iudaeos defecit, et circumcisus est. Dehinc hebraica lingua, et eorum litteris institutus privatam editionem exorsus est. Qui quidem in plerisque cum Septuaginta consentit, quod in eorum lectione tritus, ac longa consuetudine exercitatus fuerat".

34 Sw. Ireneusz / + 202/ w "Adversus haereses" /III 21, 1, SCh 211, 398/z lat 180-185 mówi, że Teodocjon pocnodzący z Efezu 1 Akwila z Pontu, obaj pochodzenia żydowskiego, błęnie przełożyli tekst Iz 7, 14 posługując się słowem "neanis" zamiast "parthenos". Z wy. powiedzi tej wynika, ze w przekonaniu Ireneusza przekład, który on przypisuje Teodocjonowi, został dokonany przed przekładem Akwili z Sinope w Poncie, który działał za cesarza Hadriana/117138 /, a więc koniec I w. i sam początek II wieku. Nie byłby to zatem przekład owego Teodocjona z Pontu, który, według śriadectwa Epifaniusza, tłumaczył Stary Testament pod koniec II wieku. Opierając się na świadectwie Ireneusza egzegeci nazywają ów grecki przekład Księgi Daniela, istnfejacy obor przekładu LXX vor- lub proto-Teodocjonem. J. Ziegler/dz.cyt.,61/ jest zdania, że kodeks $B$ /watykański/prezentuje ten właśnie tekst. Idąc za zdaniem A. B. dau'a /dz॰cyt., 21, 23/ uwaźa, iż ten starożytny przekład został poprawiony w oparciu o tekst hebrajski, ale dość pobieznie, bo w stosunku do tekstu masoreciriego wykazuje pewne opuszczenía. To ten przekład poprawiony w jego przekonaniu stanowi dzisiejszy prz kład T-Daniela. W swoim krytycznym wydaniu greckiego przekładu Księgi Daniela oznacza go znakiem "$\psi /$ por॰ dz•cyt.,28, przypis $1,61 /$.

35 Por. J. Ziegler dz.cyt., 28-31. Minuskuł 88 zawiera zarówno tekst LxX-Daniela/kaxiy: 135a - 172b/, jak tez tekst T-Daniela/karty $189 a-226 a /$. F. Field czesść tegoź kodeksu zawierającą tekst LXX oznacza numeres 87 .

36 Antiquitates Judaicae $\mathrm{X} 207=\mathrm{Dn} 2,35$. 
/J.A. Montgomery ${ }^{37}$ znajúuje w niej sześć cytatów, R. H. Charles ${ }^{38}$ sześć następnych, a $P$. Grelot ${ }^{39}$ jeszcze dalszych trzy/. Bardzo ciekawe jest też spostrzeżenie J. Gwynna ${ }^{40}$, a mianowicie, że istnieje dość ścisłe powiązanie nyrazowe między greckim przekładem Księg1 Barucha $/ 1,15,16,18 ; 2,2,7,11,14,16 /$, a przekładem T-Daniela.

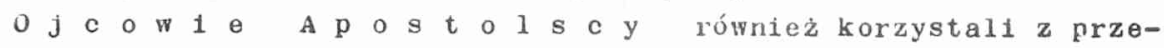
kładu T-Daniela zwłaszcza św. Klemens Rzyıski 1 Hermas w "Pasterzu", jakkolwiek wiadomo, że posługimali się oni także przekładem LXX-Danie1a. To samo stwieruza się u św. $J$ u s t y n a $/+165 /$ w "Dia$\log \mathrm{z}$ Żydea Tryfonem"1, u s w. I r e n e u s z a $/+202 /$, a przede wszystkim u jeğo ucznia św. II $i \mathrm{p} 011 \mathrm{t}$ a $\mathrm{R}$ z y m s k $\mathrm{i} e-$ g o / $235 /$, który pozostawił cztery księgi komentarza do Księg1 Daniela w Jezyku greckim, opartego na wersji $\mathrm{T}^{42}$. J. Ziegler ${ }^{43}$ stwierdza, że wysoka wartość tego komentarza dla poznania tekstu greckiego T-Daniela obniża jednak fakt, iź wiele wierszy w ogóle nie przekazuje /w sumie 125 wierszy na 530 wierszy całości tekstu Daniela/, niektóre nie są cytowane dosłownie, tekst zaś cytowanych wierszy w samym komentarzu w wielu przypadkach jest bardzo rozrzucony.

Przy omawianiu przekładu LXX-Daniela zauważylímy, że gdy chodzi o Kościół Wschodni, to o r y g e n e s / + 254/ posługiwał się w zasadzie przekładem T-Daniela. Gdy zaś w jednej z homilii do Księgi Liczb cytował tekst Daniela według wersji $L_{x x}{ }^{4}$, to równocześnie przytaczał

37 Dz.cyt., 47-49.

38 Dz.cyt., LIV.

39 Art.cyt., 390.

40 Theodotion, Dictionary of Christian Biography, t. 4, London 1887, 970-979. Cytowany za A. Di Lella, dz.cyt., 80-81.

$41 \mathrm{~J}$. A. Montgomery, dz.cyt., 48.

42 Por. B. Altaner - A. Stuiber, Patrologie, Freiburg 1980 8, 167: "Hippolyts Danielerklärung ist der alteste Kommentar zu éinem biblischen Buch, der uns aus der alten Kirche erhalten ist". Komentarz św. Hipolita zachował się jednak tylko w urywkach/PG 10 , 637-700/. iN całości istnieje w przekładzie starocerkiewnosłowiańskim. Prawie cały komentarz zawiera rekopis w klasztorze Vatopedi /Góra Atos/z X-XI w., źle zachowany i mało czytelny. Rękopis natomiast z klasztoru Meteoron/Córa Atos/dobrze się zachował, ale nie zawiera całego komentarza. Por.J. Ziegler, dz.cyt., 32-34.

43 Dz.cyt., 33-34; tenże, Der Bibeltext im Daniel-Kommentar des Iippolyt von Rom. Nachrichten der Akademie der Wissenschaften in Gottingen. I. Philologisch-Historische Klasse. Nr.8, Gottingen 1952, 163-199; M. Richard, Encore le probleme d'Hippolyt, "Melanges de Science Religieuse" 10/1953/13-52, 145-180.

44 In Numeros hom. 18, 3, PG 12, 715 - Dn 1, 17, 19b-20. 
ten tekst w przekładzie łacińskim, który pokrywał się całkowicie z wersja $T$, ale nazywał go tekstem Hebrajczyków. E u z e b 1 u s z z C e z a r e i / $\quad$ +333/w swoich "bklogach", raz cytował przekład LXX-Daniela, innyw znów razem posłajiwał Gię przekładea T-Daniela ${ }^{45}$. Równiez w Kościele Zachodnim zaczęto się coraz częściej posługiwać przekładem r-Daniela. Tak na przykład u $\mathrm{T}$ e $\mathrm{r}$ t $\mathrm{u}$ l $\mathrm{i}$ a $\mathrm{n}$ a /+220/w "Adversus Judaeos" znajduje się dłuższy cy̧tat sụonujący przekład T-Daniela ${ }^{46}$. Także św. C y p r i a n / $258 /$ korzystając z Księgi Daniela, oprócz wersji LXX, posługiwał się wersją T. J. Ziegler ${ }^{4}$ wylicza nawet pisma, w których są cytaty z wersji T, a mianowicie: "Testimoniorum libri III ad Quirinum", "De dominica oratione", "De opere et eleemosynis"48. Analogiczne cytaty sa ponadto w pismach tzw. Pseudo-Cypriana: "Ad Novatianum", "De pascha computus" 1 "Oratio Cypriani quam sub die passionis suae dixit" 49.

W 2. poł. IV i w V wieku, tak w Kościele Wschodnim, jak i Zachodnim pusługiwano się już prawie wyłącznie wersją T-Daniela. Tak na przykład komentarz św. J a n a C h r y z o s t 0 m a / $/ 407 /$ do Księgi Daniela opiera się już tylko na wersji T. Zachował się on jednak tylko w urywkach przekazanych w katenach ${ }^{50}$, z brakiem ok. 244 na 530 wierszy całego tekstu Ksiegi.Charakterystyczne jest w nim to, że opowiadanie o Belu i snoku/Dn 14/, z którego sa cytowane tylko dwa pierwsze wiersze, następuje bezpośrednio po ostatnim wierszu czéści protokanonicznej, tj. po w. 12, 13. Ŝw. H i e r o n $i \mathrm{~m}$ /+ 420/, opracował swój komentarz do Księji Daniela, jak już wspomniano, w oparciu o wersje $\mathrm{T}^{51}$. Na tym równiez przekładzie opiera

45 Por. Eclogae propheticae III 44145, PG 22, 1173 i $1176-$ Dn 7 , 13-14 i Dn $9,22 b-27$.

46 Adversus Judaeos 8, 1-10, $\operatorname{CCL} 2,1356-1359-\operatorname{Dn} 9,1-2 \mathrm{a} ; 9,20-27$ 47 Dz.cyt., 25.

48 Ad Quirinum testimoniorum I 4, III 10, III 20, CCL 3, 9, 98, 116117,- Dn 12, 4, 7c; Dn 3, 16-18; Dn 3, 37b - 42, 13, 1-3, 6, 2428; De dominica oratione $8, \operatorname{CCL} 3 \mathrm{~A}, 93-\mathrm{Dn} 3,51 ;$ De opere et eleemosynis 5, CCL 3A, 58 - Dn 4, 24 .

49 Ad Novatianum 17 , PL 3, 1217 - Dn 7, 9-10; De pascina computus 13, PL 4, 958-959 - Dn 9, 24-27; Oratio Cypriani quam sub die passionis suae dixit 2, PL 4,907 - Dn 14, 37-38.

50 Jest to zhiúx ok. 230 scholionów przypisywanych św. Janowi Chryzostomowi, por. $\mathrm{PG} 56,193-246$.

51 Por. notę 27. 
się komentarz do Księgi Daniela $P$ o l i c h $\mathrm{r}$ o $\mathrm{n}$ i u $\mathrm{s}$ z a z A p a m e i / 430/, z którego zachowały się niestety tylko Pragmenty $w$ scholionach ${ }^{52}$ zebranych $w$ katenach do Wielkich Proroków, wydanych przez M. Faulhabera ${ }^{53}$. Podobnie ma się rzecz z komentarzem do Ksiegl Daniela $\mathrm{T}$ e o d o r e t a $z$ C y $\mathrm{r} u$ $/+458 /$, jednego z najlepszych egzegetów greckich ${ }^{54}$. W wielu przypadkach tekst nie jest cytowany dosłownie, a ok. 69 komentowanych wierszy nie ma przytoczonego tekstu biblijnego. Pierwsze dwa wiersze rozdz. $14 / 0$ Belu 1 smoku/sa komentowane bezpośrednio po wierszu 12, 13. Brak jest jednak, tak komentarza, jak 1 dalszego tekstu rozdz. 141 całego rozdz. 13 /opowiadanie o Zuzannie/ ${ }^{55}$.

Powyższy przegląd patrystycznych wypowiedzi pozwala stwierdzić, ze przekład T-Daniela nie tylko istniał, ale był w użyciu wościele już w 2. poł. I w. po Chrystusie. Musiał się on cieszyć dużym autorytetem, skoro posługkwano się nim, by uzupełnić lub poprawić przekład LXX-Daniela, a nawet zaczęto go nim zastępować uważając, ze jest lepszy $i$ wierniejszy w stosunku do oryginalnego tekstu hebrajskiego-aramejskiego. Komentarze do Ksiegi Daniela tak wybitnych ojców Kościoła, jak św. Hipolit Rzymsk1, św. Hieronim, św. Jan Chryzostom, Polichroniusz z Apamei i Teodoret z Cyru świadczą, że przekładem T-Daniela posługiwano sie prawie powszechnie już w III w. tak w Kościele Wschodnim, jak 1 Zachodnim. Natomiast przekład LXX-Daniela zaczął szybiso zanikać.

Badania pism Ojców i Pisarzy Kościoła, w których pojawiają się cytaty 1 aluzje do Księgi Daniela, obaliły długo utrzymujące się przeświadczenie, że grecki przekład LXX był pierwszym 1 jedynym greckim przekładem wszystkich ksiąg Starego Testamentu do II wieku. Fakt istnienia cytatów i aluzji z Ksieggi Daniela w jężyku greckim, bardzo podobnych w formie $i$ w słownictwie do przekładu Teodocjona z końca II w. wcale nie przesądza, że ten różny od LXX przekład pochodzi od Teodocjona. Cytaty 1 aluzje do tego właśnie przekładu, różnego od LXX, a tak podobnego do przekładu

\section{PG 93, 13-470.}

53 Die Propheten-Catenen nach romischen Handschriften. Biblische Studien IV, 2-3, Freiburg i.Br. 1899, 165-166. 181-182.

54 Commentarius in visiones Danielis prophetae, PG 81, 1255-1546. 55 Por.J.Ziegler, dz.cyt., 36 . 
Teodocjona, w greckim przekładzie Księgi Barucha, w greckim przekładzie 1 Księgi Machabejskiej, w księgach Nowego Testamentu/Ewangelie Marka 1 Mateusza, List do Hebrajczyków 1 Księga objawienia/ 1 w pismach Józefa Flawiusza dowodzą, że ten przekład istniał w I w. 1 by powszechnie znany. W stosunku do przekładu Teodocjona był ponad jeden wiek wcześniejszy, w odniesieniu zaś do tekstu oryginalnego był wierniejszy niż LXX. Świadectwa ojców pozwalają przyjąć, że tym przekładem posługiwano się już w początkach II w. na równi z przekładem LXX-Daniela, z tym, że zyskiwał on sobie coraz to większe uznanie $i$ autorytet.

W oparciu o samo korzystanie z tego przekładu przez ojców i Pisarzy Kościoła jest dość trudno urobić sobie carkowicie pewne zdanie o jego genezie. Stanowi ono tym niemniej rzeczowa podstawę do tych hipotez, jakie na ten temat obecnie istnieją ${ }^{56}$. Dzięki świadectwu ojców i Pisarzy Kościoła można twierdzić, że tak przekład LXX-Daniela, jak też przekład T-Daniela od począìku zawierały części deuterokanoniczne Księgi Daniela, a całą tę Księgę zaliczano do zbioru Proroków. Takiego zdania byli Qumrańczycy ${ }^{57}$, Józef Fla-

56 W różny sposób usiłują egzegeci wyjaśnić genezę tego przekładu. J. A. Montgomery /dz.cyt., 50/ jest przekonany, że tzw. Ur-Theodotion istniał juz w I w. przed Chr. w formie hellenistycznego ustnego targumu. Za istnieniem tego przekładu w I w. przed Chr. opowiada się S. Jellicoe/Some Reflections on the KAIGE Recension, VT 23/1973/23-24/. Możliwość istnienia takiego przekładu już w tym czasie zdają się potwierdzać fragmenty greckiego przekładu Dwunastu Proroków odkryte w Wadi Khabra/Nahal Heber/ na południe od Wadi Murabbacat z I wo przed Chr. 1 z wczesnych lat I w. po Chr. zwłaszcza, że technijka przekładu jest ta sama, co w przekładzie T-Daniela. D. Barthélemy/Les devanciers d'Aquila. Premiére publication intégrale du texte des fragments du, Dodekapropheton trouves dans le désert de Juda précédé d'une étude sur les traductions et recensions grecques de la Bible réalisées au premier siècle de notre ère sous l influence du rabbinat palestinien, VTSupl.10, Leiden 1963, 148-150/ sąuzi, że T-Daniel nie jest przekładem, lecz recenzją, której dokonał Jonatan ben Uzziel, uczeń R. Hillela przed $50 \mathrm{r}$. po Chr. Poprawił on istniejący przekład LXX-Danfela tekstem hebrajskim, żeby był nierniejszy oryginałowi, ale poprawki te nie są tak radykalnie dosłowne jak u Akwili. A. Scimitt/stamit der sogenannte "V" "-Text bei Daniel wirklich von Theodotion. Nachrichten der Akademie der Wissenschaften in Gottingen. I. Philologisch-Historische Klasse, Nr. 8, Gottingen 1966 /przypisuje przekład T-Daniela Symmachowi /ok. 200 r. po Chr.

57 Por. fragment 4 Q 174 datowany na lata 31-30 prz. Chrystusem. 
wiusz ${ }^{58}$ oraz rabinaccy nauczyciele Amoraici i Tannaici.

Trudno jest podać przekonywujące racje, dlaczego w stosunku do Księgi Daniela przyjął się w Kościele przekład T, a nie LXX. Być może, iż wpłynął na to fakt, że przekład $\mathrm{T}$ pojawił się równıe wcześnie, jak i przekład LXX. Ponieważ zaś powstał w środowisku palestyrískim $i$ był wierniejszy oryginałowi hebrajskiemu-aramejskiemu Księgi Daniela, ஐzbudzał większe zaufanie. Jeśliby się przyjęło wnioski J. Schtupphausa, dotyczące części deuterokanonicznych Danie$1 a^{59}$, rozciagając je również na częśc1 protokanoniczne tak wersji LXX, Jak $1 \mathrm{~T}$, to moźna by sugerować, że przekład T dlatego tak szybko się przyjał i całkowicie wyeliminował z uźycia w Kościele wersje LXX-Daniela, iź bardziej odpowiadał duchowym potrzebom wiernych narażonych na prześladowania: dodawał bowiem otuchy i budził nadzieję nagrody. Przekład zaś LXX-Daniela akcentował raczej wierność prawu Bożemu, zachęcał do trwania w tej odmienności życia i postępowania w stosunku do otaczajø̨cego pogaństwa, jaka winna cechować wierzącego Izraelitę czy chrześcijanina. Sugerował przetrwanie, a te ideały prawdopodobnie mniej przekonywały i mniej pociasały. A. Bludau 60 sądzi, że o odrzuceniu przekładu LXX-Daniela zadecydowało nie dość wierne tłumaczenie tekstu Dn 9, 24-27, bo nie pozwalało tej perykopy rozumieć Jako zapowiedzi przyjścia Mesjasza w osobie Jezusa Chrystusa; totez Tertulian, w tym przyoadku, przyją wersje T.

W ostatecznej konkluzji trzeba przyznać, że wszystkie dotychczasome próby uzasadnienia, dlaczego w całym Kościele przyjęła się wersja T-Daniela są tylko hipotezami. Jestem przekonany, że mamy tu do czynienia z bardzo charakterystycznym dowodem istnienia 1 działania w Kościele owej ważnej zasady hermeneutycznej, dotyczącej autentycznej interpretacji tekstu biblijnego, określanej mianem sensus Ecclesiae, która jest niewątpliwym znakiem działania Ducha Swiętego w Kościele. Pisma Jjców i Pisarzy Kościoła w odniesieniu do Ksiegi Daniela bardzo ułatwiaja jej dostrzeżenie.

Ks. Júzef Homerski - Lublin

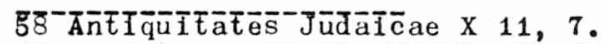

59 Art.cyt., 60-62, 68-69, 71-72.

60 Dz.cyt., 24 . 


\section{DE VERSIONE GRAECA LIBRI DANIELIS IN TESTIMONIIS PATRUM /Argumentum/}

Sic dicta graeca versio Theodotionis libri Danielis iam saeculo I p.Chr. exstitit. Ergo plus quam unum saeculum ante 111 um Theodotionem viguit, de quo S. Eplphanius scripsit, eum/i.e. Theodotionem/ genere Ponticum teipore Commodi imperatoris/180-192/vixisse et Sacras Litteras e lingua hebraica vertisse/PG 43, 264/. Haec libri Danielis versio Theodotionis ob suam originem palestinensem ut existimatur - et propter maiorem pidelitatem erga hebraicum exemplarem, communitati fideiium magis, quam eodem tempore vulgata versio Septuaginta interpretum $/ L X X /$, placere videtur. Atque fidelium ingenio et religiosa expectatione quam maxime proficiens, a dimidio saeculi II p.Chr. versionem LXX-Danielis prius in Ecclesia Orientali superare incipit, ac saeculo III p.Chr. in universa Ecclesia eius locum occupavit. 